\title{
The Natural History Museum needs the best of both worlds
}

SIR,--The current controversy concerning the Natural History Museum's new exhibition scheme and philosophy, eptiomised in the opposing views expressed by Drs Miles and Halstead (26 October, page 683), highlights problems which certainly deserve the "fullest possible public discussion" as Halstead suggested. While my personal opinion is no more (or less) valuable than that of the next man, as the father of two of the museum's avid users, and also as an ex-curator of one of its scientific sections, I can, at least, see the situation from two different points of view and can make some observations rather more frankly now than when I was still a staff member.

The tremendous gulf between the expressed views suggests that the fundamental question of the museum's role remains to be resolved-despite two centuries of more or less continuous discussion. No-one would dispute the fact that the museum has two distinct general functions, both clearly identified, as Miles points out, by the British Museum Bill of 1753 , and as valid today as they were then. The first of these, to carry out research into the natural world, occupies almost two-thirds of the museum's total complement of 750 and sails serenely on with hardly a ripple from the outside world to rock the scientific boat. It is the second, more public role, which attracts all the attention even though it is dealt with on only seven sides of the museum's most recent 170 page report to Parliament.

But while these general functions have remained unaltered, the techniques and approaches needed to discharge them have changed, and will continue to change, throughout the museum's existence. For just as it would be totally inappropriate for the present scientific staff to approach their work in the same manner as their Georgian predecessors, the public galleries should surely bear little resemblance to those of 200 years ago. For one thing, both in numbers and in social stratum, the public served then was very different from that using the museum today. In its early years no more than a few dozen privileged visitors could view the British Museum exhibits each day-and even then only by appointment with a Keeper; as a son of the eighteenth century equivalent of a lorry driver I would personally have had little chance of stepping through the door, let alone of becoming a Curator!

Second, the museum now operates in a different educational environment. The present-day flood of scientific information for the "layman" through books. films, radio and, above all, television did not exist ten, or even one, generations ago. No museum exhibit should attempt to compete with the slickness and immediacy of a television presentation. for whatever vou may think of their particular contributions. a Bellamy or a Cousteau can reach a larger and more varied audience in one hour than the $\mathrm{BM}(\mathrm{NH})$ could hope to reach in ten years. Surely

the museum should adopt a complementary role in these circumstances, concentrating its efforts on those things which it can do better than the mass media by exploiting its particular strengths, its in-house scientific know-how and its vast collections of material.

The official museum view of the way forward seems to be to attempt to put over concepts and ideas to a general public largely devoid of any background in natural history. The opposing

"Halsteadian" view, which appears to have the support of a significant proportion of the museum's own scientific staff, seems to favour a return to a more traditional type of "scholarly" display with many examples of the animals, plants and minerals themselves from which the informed visitor can draw his own conclusions. Either approach alone would be dangerous, sterile and damaging to an institution for which so many of us feel the deepest affection. If $\mathrm{Dr}$ Miles really believes his survey results which told him that the old displays taught virtually nothing, he should have been with my wife and I when we took our 6-year-old son on his fifth or sixth visit to the museum some years ago. After a depressing appointment with a child psychiatrist had confirmed that he had severe learning difficulties, we were considerably encouraged to have him point out to us the differences between African and Indian elephants in the now dismantled Main Hall exhibit! Like most kids he still likes to see lots of dinosaurs, whales, fishes and so on, and much prefers them to the Hall of Human Biology, which, after its first month, was looking pretty dog-eared by the time we got to it. On the other hand, Dr Halstead's plea for "scholarship" seems equally pathetic. He must realise that not many of us would come up with an evolutionary theory from a perusal of a Cuverian arrangement of specimens, while I cannot imagine what diabolical deeds he envisages the "more inarticulate sections of the community" being incensed to perpetrate as a result of exposure to the Natural History Museum's "social engineering".

However, I feel much more sympathy for Halstead's main worry of a "serious breakdown of communication between the museum's Department of Public Services and the scientific staff . ...". It's all very well to cite the dismay of the museum's "world leading ichthyologist" and "dinosaur expert" at the loss of the exhibits of their respective groups, but they didn't reach their present eminent positions on the strength of their efforts in the exhibition sector. For like the rest of the scientific staff they know that their professional advancement has depended entirely on publication; time devoted to exhibition work has therefore tended to be spent grudgingly and, at least in the past, was often restricted to topping up a dried out bottle or replacing a lost label. Under such circumstances it is little wonder that a them-and-us situation developed between the public and private sections of the staff, with the scientists taking little or no interest in the exhibits for which they were nominally responsible. The scientists can't expect to have their cake and eat it, for if they want a real say in the fate of the exhibitions they must be prepared to be involved. In return, the museum establishment must demonstrate the value they attach to such involvement in terms of career structure and promotions. The Department of Public Services seems to have evolved to fill a gap resulting from the mutual distrust felt on precisely this point.

If there are now two quite distinct, but genuinely held, opinions of the type of exhibitions which the museum should mount in the future, it is surely not too late to exploit the best features of both views. The projected building programme within the museum's existing walls is supposed to provide four times the existing exhibition space over the next three decades. Such an expanse must be capable of housing the traditional scholarly exhibits favoured by Halstead, the exciting new conceptual approach advocated by Miles, and the fun exhibits which the dominant less than 11-year-olds can stare at in wonder and awe and remember in the recesses of their mind for the rest of their lives.

Yours faithfully,

Cranleigh, Surrey,

A. L. RICE

UK

\section{New policies are correct}

Sir,-There seem to be three separate strands in the recent controversy on the new display policy of the British Museum (Natural History): whether displays should be for scholars or for the general public, whether they should be organised by research scientists or by exhibition staff. and whether the former balance of displays should be retained. In each case, I believe that the new policies of the BM(NH) are basically correct.

Until recentlv, the majority of the displays were little more than a collection of labelled specimens. There was little attempt to point out any features of particular interest, or to help the visitor to appreciatc their significance to current scientific theory. Even those displays directed towards university students were suited to a level of knowledge that was not usually attained before the second year of a zoology degree. Similarly, those exhibits that were directed at the reasonably well-informed adult were accompanied by complex and lengthy labels, their comprehension requiring a considerable degree of dedication and time. Finally, many of the exhibits were so old-fashioned 
as to merit illustration in any book of the history of museum display technique. It can be no surprise that the majority of the visitors to the museum had, as Dr Miles stated "learnt practically nothing". It is surely appropriate that the museum should attempt to inform, as well as interest, the throng of children and of scientifically uneducated adults who nowadays pack its halls.

Should we really expect that the prime responsibility for the new exhibition approach should rest with the scientific staff, already committed to programmes of research and curation? It is no secret that, in any museum, many research workers have little interest in the problems of the design of displays, even if they are of completely conservative and scholarly type. It is even more unlikely that many of them would wish to learn and to apply the theory and techniques of modern displays directed at those with no scientific qualifications. (This is not to say that the scientific staff should have no role in this, and many of those at the BM(NH) certainly seem to feel that they have not had sufficient opportunity to comment on the new policies, or to ensure that the scientific theories illustrated are appropriate and not merely those currently in vogue).

The balance of exhibits is a complex matter. I feel that it is only appropriate that the museum should attempt to let visitors understand themselves as human examples of the world of nature, and to educate them in the basic processes of ecology. (Not even the museum display staff would pretend that every exhibit in the Hall of Human Biology is an unqualified success, but even the $\mathrm{BM}$ (NH) must surely be allowed to make the occasional mistake).

Furthermore, there can be no doubt that invertebrates and plants have in the past received a totally inadequate proportion of exhibition space. It was therefore inevitable, and only right, that the new exhibits should be at the expense of the great range of extensive (though mainly old-fashioned) displays of living and fossil vertebrates. It is natural for vertebrate zoologists to regret this, but we should surely be reassured by Dr Miles' statement that the new exhibits "will contain the vast majority of the material now on show in the museum". Yours faithfully,

King's College, London

\section{BARRY COX}

\section{Links with school}

SIR,--As a teacher of biology, I would like to offer my views about the recent article entitled 'Whither the Natural History Museum?' by Dr B. Halstead

My earliest recollections of the museum are those of my childhood. when I was taken on the usual tour of the museums on a trip to London. I remember, most of all, the dinosaurs but little else except endless rooms of glass cabinets full of bones and a lot of unpronounceable words

Today, thankfully, the presentation of material in the museum is progressing and the two most prominent examples of this are the new exhibitions of human biology and ecology. These offer a new and very important dimension to the role of the museum-namely a vital resource which links important aspects of natural science with what is being taught at school

I have been lucky enough to use the exhibition of human biology as part of my exam course in the fourth and fifth years.
The pupils concerned were taught how to use the exhibition and, as a result, were able to benefit from it in a way they could not by just relying on textbooks at school. I look forward to using the ecology exhibition in the same way with my second year groups next summer. The

publications accompanying the two exhibitions also allow for follow-up work at school.

From Dr Miles' figures regarding visitors to the museum, it would appear that these exhibitions will benefit an age group whose presence is sadly missing from the museum.

I would like to say in conclusion that the museum should continue to present its rare and fascinating fossil exhibits, as it has done for years, thus fulfilling its role to the scholars; but also to continue with its new fresh approach and present more exhibitions which are of more use to schools and the less scholarly members of the general public. Yours faithfully,

St John's School, D. A. WEALE

Epping, Essex, UK

\section{Teachers need a say}

Sir,-I am a teacher in the fourth year of a large multi-cultural East London primary school. I am prompted to write in response to the articles by Dr Miles and Dr Halstead on the future of the British Museum (Natural History).

Dr Miles says that to some extent the Natural History Museum is for children under the age of eleven. He points to the absence of secondary school pupils and university students from the public galleries. Without doubt the primary school children are impressed by the large dinosaurs and blue whales. They take a passing interest in one or two other galleries or individual exhibits but generally scurry through the remainder of the museum if given the opportunity. To the children many of the current displaps seem unrelated to each other or to a wider theme. I am not surprised that the majority of younger visitors are not motivated to return for many years.

On the other hand the recent human biology exhibition is stimulating and dynamic and makes demands of the children. In my experience they take an active interest in the displays and are keen to seek answers to questions. Furthermore the exhibition is coherent and so more meaningful to them. Although many of the concepts explained are beyond the grasp of the average eleven year old, I anticipate that a higher proportion are likely to revisit and develop their understanding than would have done had the exhibition remained in the traditional layout. If other recommendations in the paper 'A Proposal for a New Approach to the Visiting Public' are implemented I feel that many teachers and pupils will benefit even more.

It is disquieting to hear of the rift between the Department of Public Services and scientific staff. Dr Halstead himself, however, refers to a false dichotomy, by discussing the former dinosaur gallery and its multi-level appeal. Surely the 'new style' exhibition can also be both stimulating and scholarly given the goodwill and collaboration of scientists and exhibition staff. After all Dr Miles does say that the exhibits to be displayed will contain the vast maiority of the material on show.

Dr Halstead calls for the fullest possible public discussion. Hopefully teachers at all levels will be given an opportunity to participate in this discussion which at the moment seems to be conducted at the level of the academic. Yours faithfully, L. J. Stevens

Wanstead Park, London, UK

\section{Arborescent animals and other colonoids}

SIR,-Comparative biology is sometimes hindered by terms which have become misleading with the advance of knowledge. 'Individual' and 'colony' are such terms when they are used to refer to a single polyp and the entire organism of a reef coral, for instance. The organism responds as a unit in growth and physiology, and it is also the unit of individual selection. I therefore propose two new general terms to replace 'individual' and 'colony' in such cases. Specific terms are already available in some instances, but they vary from taxon to taxon.

Individuoids are parts of an organism which have the general structure of whole free-living individuals but which connect with each other to form a coloniod. A colonoid usually has the same genes throughout and functions as a single individual.

The concept of colonoid grades into that of colony or association, which may be restricted to a group of proximate but physiologically separate individuals, usually of one clone. Intermediate cases might be grass swards or diatom chains. The concept of a colonoid organism also grades into that of individual sensu stricto, in which case individuoids may resemble organs. Examples are rooting branches of mangroves, bryozoan aviculariae, or cyanophyte heterocysts. Slime mold colonoids are colonoids for only part of the life cycle and may form (sometimes necessarily so) from individuoids of different genotypes. Such fuzzy boundaries of concepts are necessary in the real world.

A diverse array of animals grow in a treelike form. Some but not all have apical meristems. Examples of arborescent growth occur among sponges, hydroids, alcyonarians, corals, bryozoans (including entoprocts ${ }^{1}$ ), graptolites, pterobranchs, and probably elsewhere. Comparative studies of their growth and that of branched plants and protozoans, from both mechanistic and adaptive viewpoints, have always proved illuminating in my seminar course on the evolution of development and would undoubtedly be more illuminating if pursued more fully.

The study of plants and arborescent animals can thus be mutually beneficial, but such study presupposes that functionally corresponding units are identified beforehand. Studies of other phenomena, such as adaptive strategies, also need clear recognition of what units are appropriate. This has not always been done, perhaps because of the pervasive shadow of a purely morphologically based terminology, and

the result is then biological nonsense. Yours faithfully LEIGH VAN VALEN

Biology Department

University of Chicago, USA

${ }^{1}$ Neilson, C. Ophelia, 9, 209-341; 1971. 